wait for affordable AIDS drugs to become available."

Other provisions in the latest FTAA draft would extend patent terms beyond the TRIPS agreement and put limits on compulsory licensing "in direct contradiction" of the Doha Declaration, according to an analysis by the Consumer Project on Technology. Collectively, these provisions are referred to as "TRIPS plus."

The media office of the United States Trade Representatives did not return numerous telephone requests for comment.

"We've been going around to the FTAA countries, meeting with ministers of health and trade, talking about the dangers of [reduced] access to medicines and urging countries not to trade away health," said Morrison. But, in the end, the pressure on the countries has been enormous and many have buckled under, she noted.

The progress of the FTAA has been rocky - talks broke down at the latest meeting in Pueblo, Mexico in early February - but in the meantime, the US has been busy negotiating with subgroups like CAFTA and completing bilateral agreements, as with Chile.

A proposal at the Puebla meeting to enshrine the Doha Declaration into the FTAA was unsuccessful, noted Lotrowska.
"Opposition is growing, but at the moment it looks like when it is 2005 , the whole world will be TRIPS plus."

Morrison said MSF has been urging the FTAA countries to implement the Doha Declaration into national law and to use its provisions. Such a measure would at least "sit in uncomfortable" relation to any stricter proposals and act as a tool to pressure the United States.

In FTAA negotiations, Canada's official position has been that intellectual property provisions should not go beyond WTO agreements, a government official said. - Ann Silversides, Toronto

\title{
Generic Medicines
}

\section{FTAA could interfere with proposed Canadian patent legislation allowing generic exports}

The Free Trade Agreement of of the Americas (FTAA) threatens 余 to weaken or even render useless Canada's proposed federal legislation to allow the export of generic versions of patented drugs to the developing world, says Richard Elliott of the Canadian HIV/AIDS legal network.

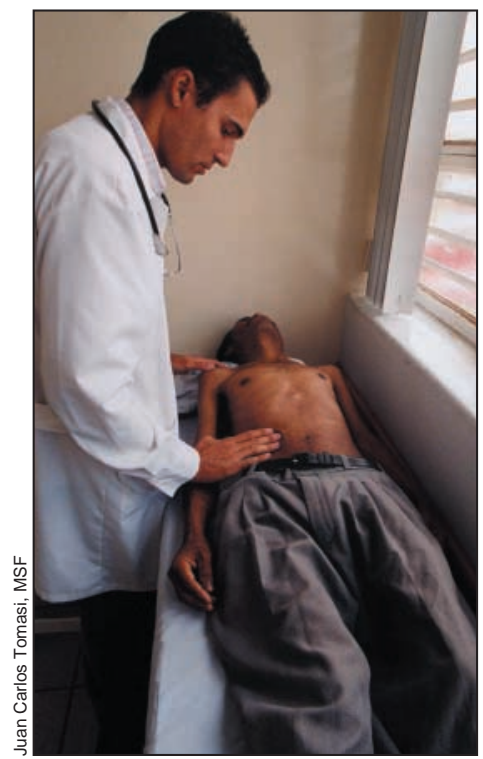

Vision of the past? Guatemalan physician Alberto de Dias examines a patient to see if he qualifies for ARV treatment.
Draft provisions in the FTAA would put major roadblocks in the way of the countries of South and Central America and the Caribbean seeking to import lifesaving generic drugs from Canada or elsewhere, he noted.

For example, requirements that signatories agree to 5 years of data exclusivity would seriously delay access to needed medicines. Data exclusivity means that the information used to register medicine can not be relied upon by third parties, for example for registeration of a generic product.

Similar restrictive provisions have already been enshrined in the bilateral trade agreement between the United States and Chile, and are in the final text of the Central America Free Trade Agreement.

"There are quite serious implications for Canada in these agreements," Elliott said. And if Canada were to sign an FTAA that included such restrictions, the [proposed] Canadian legislation would be "eviscerated," he told $C M A 7$.

Canada's initiative, embodied in Bill C-56, followed an August 2003 World Trade Organization General Council agreement to facilitate the Doha Declaration by making it easier for countries to import generic versions of patented drugs if they lack domestic drug manufacturing facilities.

"It would certainly give a symbolic boost if Canada refused to sign an FTAA" because of restrictive intellectual property provisions, said Elliott, whose group has been closely involved with the formation of the domestic legislation. "But I am not holding my breath."

However, a Canadian official engaged with the FTAA's intellectual property negotiations, who requested anonymity, expressed certainty that "we would see to it not to sign an agreement preventing us from what we are doing at the domestic level ... quite frankly how could we on one hand pass legislation allowing us to do something and then sign an agreement" making this impossible? - Ann Silversides, Toronto 